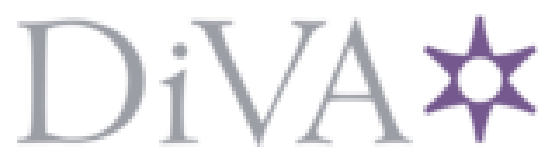

http://www.diva-portal.org

\title{
Postprint
}

This is the accepted version of a chapter published in International Handbook on Giftedness.

Citation for the original published chapter:

Persson, R. (2009)

The unwanted gifted and talented: A sociobiological perspective of the societal functions of giftedness.

In: Larisa V. Shavinina (ed.), International Handbook on Giftedness (pp. 913-924). Dordrecht: Springer Science

N.B. When citing this work, cite the original published chapter.

Permanent link to this version:

http://urn.kb.se/resolve?urn=urn:nbn:se:hj:diva-7270 


\title{
Chapter 46
}

\section{The Unwanted Gifted and Talented: A Sociobiological Perspective of the Societal Functions of Giftedness}

\author{
Roland S. Persson
}

\begin{abstract}
How come certain highly gifted individuals are not allowed to flourish and develop although they exist in an environment that has both the means and the possibility to assist and stimulate such development? Furthermore, how come there is such an over-emphasis on a certain group of abilities in giftedness research, whereas the study of others is more or less ignored? Finally, are there gifted individuals in our midst that we actually do not want? These are questions raised and discussed in this chapter. To answer them, I propose a taxonomy of gifted societal functions based on a sociobiological framework. The phenomena of stigmatizing and marginalizing gifted individuals are discussed in this light. The chapter concludes by suggesting a number of testable hypotheses regarding the predictable outcome of gifted individuals and their function in certain social contexts.
\end{abstract}

Keywords Gifted function - Gifted and society · Marginalization . Stigmatization . Taxonomy . Sociobiology

\section{Introduction: Four Marginalized Gifted Individuals}

First in this chapter, allow me to introduce four exceedingly gifted individuals from three countries, whom I have met by chance over several years and learnt to know fairly well. They are so far, beyond

R.S. Persson $(\bowtie)$

Jönköping University, Jönköping, Sweden

e-mail: roland.persson@hlk.hj.se doubt, the cleverest, most insightful, most friendly, most concerned, the wisest and most knowledgeable people I have yet encountered. Such intellectual, social and practical prowess, one might expect, would be greatly appreciated everywhere; a formidable asset to any employer or organization and they would seem to be dream students at any educational institution. But the fact is they share a common fate: they are appreciated nowhere-and so far not at anytime, except by single individuals in their social network.

\section{James, the Canadian Potential Nobel Laureate}

James is a former Canadian "wunderkind", now in his early 40s. As a child he was already able to beat master's level chess players. Also a mathematics prodigy, an extraordinary mind when it comes to science and research, a talented footballer, martial artist and a visual artist. He always had a hunger for learning, but hated school and from what he has told me, he was quite cruelly treated in the Catholic school he attended as a child. The situation did not improve as he eventually arrived in higher education! He entered university and quickly stood out because of his exceeding brilliance. However, in surpassing even the knowledge of some of his professors, and being of different opinion than they were on certain scholarly issues, his decline in the academic world swiftly began. The fact that he was outstanding in achievement and scientific thinking did not count for much. He seems to have posed too much of a threat to a few very influential academics of that particular university. In the end, he was denied the much-desired Ph.D. program "for political reason". 
He was even told that he was denied for political reasons. He lost his place in favor of another, and much less qualified and not nearly as gifted, candidate. This rejection should be compared to what one professor who indeed supported James in his efforts had written in recommending him for the program: "...the most likely student we have ever had to win a Nobel Prize"!

Today, a father of two, he is unemployed. The societal institutions and workplaces, which could benefit enormously from his skills, generally discard him when applying to work for them. $\mathrm{He}$ is overqualified! Instead he devotes all of his time to convey his hunger for knowledge to the two sons; and teaches them in ways that would impress any highly qualified and skilled teacher.

\section{Andrew, the Athlete and Formidable Problem-Solver}

Andrew from England, in his late 30s, is a computer engineer, an exceedingly talented martial artist as well as a visual artist working mainly with computer graphics. $\mathrm{He}$ is also a well-respected sports therapist. He went to a Catholic school, as did James, the staff of which seemed to have little tolerance for a gifted child with particular talents and more particularly with Andrew's independence and having a will of his own. He did not attend school a great deal of time as a child and was more often to be found in the local Dojo improving his skills in martial arts. He grew more skilled than even his instructors and refused to go for a black belt in karate for which he was overly qualified. He saw no meaning in doing so since he was still much better than his black-belt instructors. He now works for a large European computer company and solves problems at a pace and efficiency matched by few others in the same workplace. However, he is often at odds with superiors because they find it hard to accept that he, and not they, has the exact solution to emerging problems. The employer rather tries to "streamline" him into fitting the generally organizational company culture; even with the help of organizational psychologists. This is a futile task, which Andrew finds ridiculous and demeaning. The company strategy tells more of its ignorance in handling gifted employees rather than Andrew's argued shortcomings as a "typical" representative of the company. In his own words:
A couple of months ago at work we were sent to a team developer because our department is "dysfunctional". The questioning was painful and some of it was so basic it felt like an insult to my intelligence. But I decided to go along with it and was so blunt there was no room for misinterpretation. The result that came back from this was because I let things slide at work simply because my colleagues aren't able to do stuff I can, they said. I see myself as a victim in the team and act that way. In a way, I agree but in other [things they said] I disagree. This is simply because when you cannot change things with idiots around you why beat your head against a wall to do it. There seems no logic in it. This I didn't even bother to explain to the psychologist. Why get into a discussion of sociology, psychology and group function with an [individual] who is so fast to box people?

\section{Peter, the Polymath with Street Smarts Beyond Comparison}

Peter is a Swedish young man in his mid-20s. He hated school enough to refuse to continue any further formal education following secondary school. He was so badly treated at school that he will not even touch a book unless he absolutely must. In spite of having reached his mid-20s he has no permanent job but survives on odd jobs and considerable "street smarts". In fact, at the time of writing this he has also resigned from a part-time job, but still makes a decent living by simply knowing how systems work and people in them. In the eyes of "talent hunters" and meritocrats there is not much tangible to go on in Peter's case. None of these would consider him gifted because he does not really fall into any traditional "giftedness category". However, to have a conversation with him, to hear him speak his mind, how he reasons on practical as well as social issues, reveals a considerable depth of mind, knowledge and self-awareness. He knows how to find knowledge and information from other sources than written media very effectively. His memory is astounding. What strikes me the most about Peter is his immense self-awareness and integrity. He is exceedingly systematic, knows exactly what he can do and what he cannot do. It is also my impression that since society as such has offered him very little, even unfairly worked against him at times, he has little respect for formal authority. He sometimes therefore stipulates his own rules on how to act and exist, which, however, never excludes a social pathos. He is always concerned for other's well-being. When speaking with him I often 
find myself corrected by him with an understanding smile, and he reminds me of things I have argued earlier and obviously forgotten. How can such a brilliant mind have escaped the attention and interest of the formal education system—not to mention employers?

\section{Bjorn, the Caring Intellectual Persuader}

Bjorn, Swedish, now in his mid-30s, was also plagued by teachers and school and received no stimulation at all during his school years (a full case study has been done on Bjorn, see Persson, 2005). In fact, it went so far that he decided to "limit his own capacity to think and reason" by sniffing a harmful solvent, which he argued would damage his brain only "a little". He simply wanted to fit in and "be like everyone else" and sniffing solvent, he hoped, would achieve this. Bjorn is academically gifted as well as gifted in sports. He too is an exceedingly skilled martial artist. He trains world champions even to the extent of becoming a "sensei" creating his own style of martial arts. He has single-handedly initiated and held together a world federation for organizing competitions worldwide in his sport. However, as bright as he is academically and talented in sports, his most outstanding feature is his social awareness and competence. $\mathrm{He}$ is well aware of the fact that he can probably persuade anyone to do almost anything, for the simple reason he immediately invokes confidence, leadership and competence-and he has plenty of all three! Speaking with him on this is a like having an imaginary talk with cartoon figure Clark Kent ("Superman") on using "super powers" for the good of humanity only. Bjorn is very alert to the fact that abuse of this ability is possible, but makes quite clear he has no intentions whatsoever to do so. His ethical principles are very strong and well considered. Being a qualified teacher he currently works as a special educator and solves problems that child psychiatry and formal special educational methods have not yet managed to come to grips with. He once rang me and told me triumphantly that the entire Regional Child and Youth Psychiatry Unit had come for an unannounced visit to see with their own eyes what he was actually doing when working so successfully with autistic children. Rumors about this had spread wide and afar. Once the Chief Psychiatrist had literally applauded him in amazement, the rest of the visiting delegation chimed in enthusiastically. Bjorn's comment to this was "Ha! and I am not even a PhD!" However, the recognition did not lead anywhere; it accomplished nothing more than to satisfy the curiosity of the RCYP Unit. Bjorn has solutions and wellfunctioning practices as a teacher, derived from solid theoretical knowledge. He produced better results than most, yet he continues to be left to his own devices in spite of some recognition. Elsewhere other special educators continue to struggle with the problems that Bjorn in part has solved.

Bjorn wants to pursue a Ph.D. and discussed this with high officials at a neighboring large and quite well-known university. The officials were stunned at his prowess and considerable knowledge. But when applying, he is still never found to be "what they want". He simply does not "fit in". He is too clever by half and seems much too independent in thinking and doing to arouse the curiosity of academics in his own field to take him on.

These four individuals share certain astounding features. They are all, but perhaps in slightly different ways, as follows:

1) They are exceedingly and socially aware (or socially intelligent).

2) They are astoundingly self-aware.

3) Their skills are rarely recognized and appreciated, not even where they reasonably should be recognized. They are social "misfits" in spite of having a considerable social pathos. They are either outsiders by choice or made outsiders by others.

4) All four are polymaths-gifted in several ways multitalented (see Root-Bernstein, this volume). Finally, and this is possibly the most crucial aspect shared by them.

5) They seem to pose a threat to certain individuals, not necessarily all, as they try to rise upwards in social hierarchies (be it either in an institution of formal education, a manual labor workplace, in an organization or company or in a school). They have become accustomed to being treated as more or less unwanted; an inconvenience. Few, if any, in the societal establishment, could care less whether these individuals are correct in what they do or say. Thus, they are not only to some extent stigmatized because of what they know and how they employ in practice what they know, they have also become, in sociological terms, marginalized. 


\section{Involuntary Stigmatization and Voluntary Marginalization}

The social dimension of giftedness is nearly always missing when scholars and practitioners debate, discuss and publish on matters of giftedness and talent (Persson, 1999), and particularly questions on what function gifted individuals have or will have in society. This then is the objective of this chapter: to explore functions and the possible causes of stigmatization and marginalization of gifted individuals that appear to accompany certain types of giftedness.

The following questions will be explored: How come certain very gifted individuals are rarely allowed to flourish and develop although they exist in an environment that has both the means and the possibility to assist and stimulate such development? Note that I am not referring to able underachievers (Montgomery, 2000) or the so-called gifted disadvantaged (Wallace \& Adams, 1993). Furthermore, how come there is such an over-emphasis on a certain group of abilities in giftedness research, whereas others are more or less ignored? Finally, is it perhaps the case that society as a whole does not want certain kinds of gifted individuals in its midst?

\section{History Provides Interesting Examples}

"Not very many 'pure creatives' go into conventional education," Shaughnessy \& Manz (1991) observe, "typically, artists, musicians, and writers find their life's work outside bureaucratic institutions which may hamper their creativity and originality" (p. 98). It is not only the possibility of being hampered within a formal setting, however, that is sometimes a problem to these individuals. They are likely to encounter difficulties outside of formal education and formal organizations too. Any textbook on the history of the arts or music will provide ample illustrations of how both visual artists and Western classical composers introducing new ideas were ridiculed and shunned in their own time and by their own immediate social context; so often so it has almost become a legendary principle: shunned and harassed whilst alive but praised and exalted when passed away and gone. To this end, Machlis (1979) summarizes contemporary music history in the following noteworthy way: "Audiences were persuaded that the art as they had known it was coming to an end, and responded accordingly. Perfectly respectable individuals in Paris, Vienna, and elsewhere hissed and hooted, banged chairs, and engaged in fistfights with strangers. Today, the works that caused these antics are enthroned as classics of the modern repertory. The men who wrote them are acknowledged masters" (p. 4).

Similarly, most of the winners of the prestigious American MacArthur Award, from a variety of fields of endeavor, also met considerable resistance by their surrounding social context when deviating too much in thinking or doing. Shekerjian (1990), having interviewed 40 of these laureates, concludes that "an unfortunate aspect of creative work is that it requires an element of risk-taking. The risk, say, of exposing your own private persona. Of revealing something not quite ready for public scrutiny. Of having to go beyond the sure footing of experience and expertise. Of having to part paths with friends and mentors. Of jeopardizing resources and making mistakes. Of suffering unintended consequences and even ruin. Society shuns its heretics" (p. 16-17). Shekerjian also makes the observation that "the MacArthur Fellows are not quitters. Even in the face of insult. Or when confronted with defeat. Or when up against humiliation, despondency, hostility, boredom, or indifference. They find a way to make adjustments, to keep at it, to stay buoyant, to believe in themselves" (p. 198).

As also Shekerjian (1990) concludes, the scientific world is by no means an exception from marginalizing and even stigmatizing members of the science community; members who distance themselves away from mainstream research and knowledge even criticize it because they suspect or have perhaps already found that alternative explanations are better than the established ones. The difficulty in attracting attention and acceptance for new, and often probably better, ideas and testable theories is infamously difficult (Segerstråle, 2000). A breakthrough, if it occurs at all, has even been outlined as a "revolution" in nature (Kuhn, 1962). Furthermore, the resistance of scientists to change their minds from the old to the new, even in the face of convincing evidence contrary to their convictions, has been termed cognitive conservatism by Greenwald (1980) and is understood by him as a defense mechanism proper, though some are prone to resist change more than others (Johson et al. 1988). 
Thus, following new insights, new knowledge, new understandings or views and opinions prompted by these, stigmatization and marginalization often follow. Crocker and Quinee (2003) define stigmatization as "[having] a social identity, or membership in some social category, that raises doubts about one's full humanity. One is devalued, spoiled, or flawed in the eyes of others ... Stigmatized individuals are often the targets of negative stereotypes and elicit emotional reactions such as pity, anger, anxiety or disgust but the central feature of social stigma is devaluation and dehumanization by others" (p. 153). Marginalization, on the other hand, as defined by Hall, Stevens and Meleis (1994), is the peripheralization of individuals and groups from a dominant, central majority. Marginalization is understood as a sociopolitical process, producing both vulnerabilities (risks) and strengths (resilience).

Why then, are some individuals stigmatized? It is very likely that this tendency has biological origins and is deeply rooted in the human species' need to live and exist in effective groups (Neuberg, Smith, \& Asher, 2003). It follows that a certain social equilibrium therefore is strived for. There is resistance to change, but not necessarily to all changes. It is safe to say that no one in a group, smaller or larger, will resist change if they can clearly understand there is tangible gain of some sort, not too distant in time, deemed desirable. However, the opposite is likely to be true also: where gain cannot be perceived, or if indeed loss of some kind is involved (loss of influence, power, welfare, perks, privileges, income, prestige, status and so on), few would be willing to accept a change lightly. Whoever purports a change involving loss, also runs the risk of being stigmatized because of it. More on this later.

Why do gifted individuals, also being gifted among other gifted, sometimes choose marginalization? Storr (1972) favors discussing personality and argues that high creatives are schizoid and therefore shuns social contexts. They prefer to be alone for lack of social understanding and interest. However, I think an equally valid explanation would be, as Shaughnessy \& Manz (1991) point out, that very creative people sometimes choose relative seclusion having realized by experience that stepping aside, leaving certain environments or at the very least avoiding much contact with others if remaining in a formal setting is best to retain their creativity, their free and independent mind. The four cases outlined at the beginning of this chapter all showed considerable social skills and a social pathos at that, and yet they were marginalized. The social context surrounding such a person would perhaps understand seclusion as regressive behavior. However, from the point of view of the person choosing relative isolation, it is more likely to be a chosen coping mechanism. If we count on a percentage of the total population being in various ways gifted, there must on occasion arise situations where one single individual is right and everyone else is probably wrong. That single individual will most likely find life problematic, since the operational principle, at least in democracies, usually is that "the majority is always right". How to deal with the fact that people are different and that people are individual is a recurring problem to democracy theorists (e.g., Benhabib, 1996). The single deviant, however, will often try to find ways of coping without losing sense of self-esteem, enthusiasm, the will to continue and so on. The literature on this "darker side" of giftedness is limited. Landau (1990) provides a few cases. One of these reports a young highly gifted girl to whom recognition appeared never to have been given, neither at home nor at school. As a result, the girl closed herself to further social contact and never again regained full motivation to hone her skills or confidence in establishing a social network. Kelly-Streznewski (1999) speaks of "the mixed blessings of extraordinary potential" in her study of 100 grownups aged 28-90. Fiedler (1999), who has reviewed this particular field of study, concludes that "along with the promise of potential come the problems of potential-problems that are often a direct effect of differing from the norm in ways that others are not necessarily prepared to deal with" (p. 434).

In summary, society and social contexts react to gifted individuals in various ways. However, social environments also react to potentials: what a gifted individual might achieve if allowed to continue. Sometimes the gifted choose marginalization to be able to cope, and at times they become stigmatized when trying to bring about a change involving a loss for a group of people or to individuals in this group. Some suggestions of change, however, are rather praised and rewarded. That which dictates being commended, praised and rewarded or reproved, harassed and in different ways even punished seems to follow specific patterns, namely patterns of social function. 


\section{Giftedness and Sociobiology}

There are, I believe, often but of course not necessarily always, sociobiological reasons for social ascendancy, social acceptance or rejection, and that this at least to a degree may explain why some gifted individuals are noticed, favored and given due attention while others are ignored and even harassed in spite of their obvious talent and suitability for certain jobs, tasks, positions, skills, subjects of study and so on. While biological determinants for a variety of human behaviors may well be complex and not yet fully understood, it would be foolishness to underplay their reality (Wilson, 2000). Testosterone, for example, decides the cognitive architecture of the brain (Duchaine, Cosmides, \& Tooby, 2001) and has even been suggested to be responsible for the development and structures of the entire human social reality (Kemper, 1990). Our general ignorance of how biology actually affect our daily lives has prompted Freund (1988) to even suggest that we need to bring "society into the body", and align our understanding of societal processes with how the body works and functions. Failing to do so, he argues, would lead to "blind social constructivism" that exaggerates the processes of society and mentality without seeing some of the real processes governing the interplay between the society and the body. It is essential, therefore, also in studying various aspects of giftedness, "that we are aware of the more primitive action and reaction patterns that determine our behavior, and to not pretend as if they did not exist. It is especially in the area of social behavior that we are less free to act than we generally assume" (Eibl-Eibesfledt, 1989, p. 3).

To put what we generally term giftedness into a sociobiological perspective, where evolutionary mechanisms play a considerable role, there is a need to understand the social functions of the phenomenon. Hence, a taxonomy of gifted behaviors as functions is needed.

\section{Proposing a Taxonomy of Gifted Social Functions}

Whomever we recognize as "gifted" is usually identified on the basis of the fact that there is a social valuepositive or negative-attributed to that label. A mathematician is no doubt gifted in his or her domain but the same may well be true of someone who society has decided to label a felon (Walsh, 2003). To say that someone is a "criminal" is to a large extent a social construction. That which is illegal in one country is not necessarily illegal in another. Concern has been raised by some researchers that the young gifted, particularly when feeling alienated (such as by stigmatization) from their social context, take to "antisocial behavior". This too is perhaps a dubious term considering that it is even more of a social construction (see Fiedler, 1999). In other words, we seek only to identify and hopefully stimulate those talents which society recognizes as particularly valuable in one way or another.

Giftedness as a construct is invariably two issues combined: a cognitive hardware (of which talent and giftedness research has uncovered a great deal) and a social response to it (of which we are relatively ignorant). It follows that if there is social significance awarded to giftedness, then giftedness also has a sociobiological function. This, in turn, means that at least at some level an inter-species comparison can be made. Wilson (2004) suggests that "human behavior can be evaluated ... first by comparison with the behavior of other species and then, with far greater difficulty and ambiguity, by studies of variation among and within human populations. The picture of genetic determinism emerges most sharply when we compare selected major categories of animals with the human species" (p. 20). A few examples of a believed beneficial social function for the gifted and talented in society are in order.

The following statement by former Indonesian State Minister for Population: Haryono Suyono (1996), as part of his address to the Fourth Asia-Pacific Conference on giftedness is a good example of anticipated "gifted function". He points out that

within a few short years the 21st century will become a transparent era with numerous opportunities and limitations. In that era superior quality human resources will be required. They will have to fulfill stringent qualifications to be able to face the finite natural and capital resources ... These resources do indeed belong to the next generations and we are obliged to preserve and even to increase these in quantity and quality ... We all have to help these gifted children and to give them the required support and, in so doing, not alienate them from their respective families and the communities, as our national heritage is the family bond. We must enhance the family to have the ability to bring their gifted children to the surface and to nurture them for the progress and future of the nation (p. 71 \& p. 77). 
Suyono's address on future needs and the significance of skilful and highly able human resources came true in a dramatic way not long after the Minister's address as the whole of Southeast Asia, and particularly Indonesia, plunged into the abyss of financial turmoil, and because of it also some social upheaval. A number of individuals in Indonesia and elsewhere then had the far from enviable task to solve problems associated with "finite natural and capital resources".

In 1985, another member of government: Dorothee Wilms (1986), then Minister of Education and Science in the former Federal Republic of Germany, addressed The Sixth World Conference of The World Council for Gifted and Talented Children in Hamburg in a way similar to that of her Indonesian colleague. She opened the conference by making the observation that

The need for excellence in Science and research, in industry and technology is increasing worldwide. No country which wishes to secure the future of its citizens can, or even may, afford to leave undetected and unsupported a major part of the intellectual and creative abilities of its people. Every society which wants to prosper and meet the challenges of the future has to rely on a high level of achievement in all its citizens ... When solving the present difficult economic, social and technological problems, but also answering intellectual and cultural questions, it is indispensable that people with outstanding abilities and the willingness for excellence co-operate ... Giving special promotion to the gifted is considered by the Federal Government an additional [and] a supplementary investment in the future ... (pp. 16-17).

Gifted individuals are often seen as "the hope of the future". Giftedness is therefore not only a phenomenon of interest to scientists and educators. Its research and pursuit also create obligations towards society (Vorbeck,1992; Tee Tao \& Ling Quah, 1999).

\section{Societal Maintenance}

A first social function should therefore reasonably be a maintenance function. "Nerd" would undoubtedly be the vernacular term for this type of individual. It is my observation that the original notion of nerd as something more or less undesirable and negative- " an individual hopelessly out of fashion, uninterested in sports and trendy past times, but has an excessive interest in books, science, arts and/or computers, usually pursued at a level well beyond the advancement expected for a certain age" (cf. MIT Nerd Test, 1998)—has changed much into its opposite. As we become more and more dependent on expertise and advanced technologywell beyond the average person's comprehension and know-how - the nerd is slowly turning into a muchwanted man or woman. If recognizing giftedness as cause for special provision in education, it is mainly this gifted function that is wanted and approved by the society. Societal institutions and market alike need the nerds as future national problem solvers and facilitators of continued profit and welfare. Among them are scientists, engineers, health-care staff, product developers, industrial designers and so on. In a sociobiological perspective, they maintain societal structures by inventions, refinements and improvements in the domain of production in which they are active. Their effort gives a society the ability to attain or maintain welfare and perhaps also strengthen existing power hierarchies in a larger perspective.

\section{Societal Entertainment}

Entertainment should not be underestimated. Labeling this function "entertainment" is by no means intended to lessen or deny gifted individuals with this type of social function their value. They fill an important and much appreciated function to a great many people worldwide in various ways.

We sometimes call these individuals "heroes" in everyday language. A hero is traditionally defined as a person of exceptional qualities who wins admiration by noble deeds. However, a hero may also be someone who has certain desirable attributes not necessarily related to anything noble, such as is probably the case with most successful and famous athletes, artists and musicians. They become involuntary leaders because they act as role models, willingly or unwillingly, for many who wish to become like them. A hero therefore is someone admired, someone we want to see, associate with or be with because they strengthen our sense of identity (Klapp, 1962; 1969) or at times allow for individuals with a relatively poor self-image to bask in their glory (Cialdini et al. 1976). Alternatively, heroes may help individuals to achieve a cathartic experience by means of, for example, a sport event or a concert (see Russel, 1993, for an overview of catharsis in sport). Nobel Prize Laureate Konrad Lorenz (1966) argued that "while some early forms of sport, like the 
jousting of medieval knights, may have had an appreciable influence on sexual selection, the main function of sport today lies in cathartic discharge of aggressive urge ..." (p. 242).

If so, no wonder that gifted individuals who offer the best possible entertainment—which of course is a form of escape from the daily stress of life, evoking dreams of an alternative (and perhaps better) reality and/or offering excitement and thrill—are promoted, popular and amongst the highest paid individuals in modern societies: popular musicians, Hollywood actors, footballers and ice hockey players, popular writers, visual artists and so on. Their skills are highly regarded and usually highly rewarded.

Observe, however, that the relationship between entertainment and existing power hierarchies and social settings tends to be an easy and trouble-free one. From a sociobiological perspective, they usually present no challenge to societal structures and existing power hierarchies. Quite the opposite, they help maintain stability in a society by simply diverting people's attention from other and more critical matters concerned with, for example, employment, equal opportunities, social welfare, education, discrimination, individual rights and so on which, depending on the society in which the live, may effect their daily lives dramatically in everything but a positive way. Baumeister (1991) sees thrills and excitements as a means to escape a life "in the fast lane". He argues that "events that carry threatening implications about the self make people want to escape. They want to forget about their identities if worries are associated with them" (p. 27).

Amongst the heroes in this perspective are, apart from athletes, also many musicians, artists, writers, filmmakers, actors and so on. But, not all of these remain within the function of societal entertainment. Entertainment might become satirical or ironic and start serving another social function, in which case their relationship to societal power hierarchies may change dramatically. Some heroes become agents of societal change.

\section{Societal Change}

As discussed earlier, not all kinds of giftedness are liked! We obviously love and adore some for specific reasons as shown above, but we also discourage, ignore and perhaps even suppress others, particularly those who have the potential to achieve societal change and where these "agents" of such change are persuasive idealists who could easily gain people's confidence. Stigmatization and marginalization become frequent phenomena in this context. Above all, when by their knowledge and insightfulness, these gifted individuals publicly expose flaws in social systems, they also potentially pose a threat to the dominance of a certain individual or group of individuals, especially so for individuals in power who have personal gains to make if systems remain unchanged.

Through history these gifted individuals have often been termed martyrs. However, the notion of a martyr in this context has a wider meaning than merely, according to religious traditions, to be someone who sacrifices his or her life for a faith or achieves something on behalf of that faith. A martyr is of course also not necessarily a gifted individual. In recent years, martyrs, as reported in the media, have become horrifically associated with terrorism and suicide bombings (Hudson, 1999). I think it fair to argue, however, that over the centuries individuals remembered for being persecuted and often murdered in their efforts to either make the world a better place or having selflessly achieved something for someone else could presumably be regarded as in various ways gifted also by contemporary theoretical definitions. It has been suggested, for example, that highly creative individuals usually lack a fit to their social context and that they have a tendency to cause more or less permanent changes in history as applied to their field of interest (cf. Gardner, 1988; Simonton, 1988; Sternberg \& Lubart, 1995). This is certainly true of some of the agents of social change. I can think of several modern examples: Nelson Mandela, Martin Luther King and Aung San Sun Ky, all of whom became Nobel Peace Prize Laureates (see the Nobel Prize Foundations excellent overview on the Internet, with motivations for all the prizes awarded and laureates' biographies: http://nobelprize.org). Also individuals like Sakharov (1991), Havel (1985), Valladares (2001) and Wu and Vecsey (1996) and many more known, and presumably even more unknown, belong to this group of individuals.

It is important to observe that I am not limiting this discussion to totalitarian political systems, more often tied to brutal persecution of dissidents. In a sociobiological perspective, democracies do much the same, but usually not as brutally! Democracy in this context is 
best understood as a system of control, which in a way is designed to save us from ourselves; that is, it is usually not possible for anyone in a leading position—or for anyone aspiring to leadership - to act without being condoned by a democratic process in which not everyone will necessarily agree to what is suggested. However, human nature as prompted by biology and evolution does not differ from one culture to another and remains the same irrespective of the political system. Hardly any position of dominance in a social structure will be abandoned lightly anywhere. And when threatened it will be defended. Only the means by which positions are defended will differ depending on available control systems. The allure of gaining power and influence is presumably and equally strong everywhere, in all groups, and at all levels of society.

I do not understand the notion of martyrdom in this context of gifted social function as necessarily something you seal by giving up your life (or more often throughout history: have it taken). A martyr is mainly someone who is made to suffer in a group, large or small, in spite of altruistic intentions for the sole reason their ability permanently change the social system in which they exist, partly or fully, is recognized by others, who interpret this ability as a threat to their own dominance in that particular context. A martyr is therefore often stigmatized.

Few would want to have such a gifted individual in their midst if they present a potential challenge for dominance in the in-group, but paradoxically the martyr's effort may well be applauded and praised by other individuals not in that particular in-group. As the saying goes: "No one is a prophet in their own country". The struggles and heroism of Nelson Mandela (1991), for example, were commended by the global community, but simultaneously abhorred by the Apartheid System and its proponents then alive and well in South Africa. They did their best to eliminate the impact of Mandela's presence.

Martyrs are no longer individuals who necessarily lose their lives untimely because of inopportune and altruistic religious deeds and convictions. They are rather gifted individuals with a profound understanding of social structures and the cause and effect within social systems. These are perhaps the ones, who in the words of British philosopher Russel (2000), are governed by three strong passions: "the longing for love, the search for knowledge and understanding and an unbearable pity for the suffering of mankind". But gifted individuals prompting social change are still under persecution-and differently so depending on the cultures and political systems in which they exist. They are often the unwanted gifted individuals; unwanted even under democratic rule.

\section{Answering the Posed Questions}

How come certain very gifted individuals are never allowed to flourish and develop although they exist in an environment that has both the means and the possibility to assist and stimulate such development-just like the four cases previously presented? In a sociobiological framework outlining the likely functions of gifted individuals in a social context (see Table 46.1), this question is not difficult to answer. Some gifted individuals may simply pose a threat to others around them; a threat to the self-esteem of some who feel somehow inferior. But in a larger perspective, they may also threat positions of power and influence at all levels of society. History provides countless examples of dissidents persecuted in a multitude of ways.

To potentially pose a threat is what makes a sociobiological framework suitable in understanding the answer to the question. Threats are handled by animals and humans alike in mainly four ways: (1) posturing, (2) submission, (3) escape or (4) attack and elimination (Barnard, 2004; Grossman, 1995). Our first choice is generally not to eliminate the threat posed by another individual. It is rather to scare him or her off by demonstrating superiority in a variety of ways (posturing). If this is successful and we are convinced of the opposing "greater strength" we may choose to escape; to simply leave in order to seek safety elsewhere (or in line with previous discussion: marginalize ourselves to be able to keep an acceptable sense of emotional and creative equilibrium). However, we may resort to forming liaisons instead. It is better to be friend and ally to perceived superiority rather than to be its enemy (submission). As a last resort, we attack and eliminate with

Table 46.1 The sociobiological functions of giftedness and talent

\begin{tabular}{ll}
\hline Social function & Popular label \\
\hline Maintenance & The nerd \\
Entertainment & The hero \\
Change & The martyr \\
\hline
\end{tabular}


the ultimate purpose of once and for all ridding ourselves of the threat. Needless to say, this has been done in many ways in all cultures and societies through history. Some incarcerate "inconvenient individuals" for no legally tenable reason. Others make them disappear and/or have them killed. But the more common way, especially in a democracy, is probably to defame, undermine credibility, ignore and/or ostracize such an individual.

How come there is such an over-emphasis on a certain group of abilities in giftedness research, whereas others are more or less ignored? What we research and study is to a large extent governed by demand. There may be an abundance of research funding available to study, for example, the corporate careers of very successful women or the nature of innovation and creativity. But there is hardly any funding available to study "street smarts" or, say, the skills of bus drivers or the expertise of a car mechanic. What we study is largely governed by cultural and political mores and goals. No less important is that we do what it takes to make a career as a scientist. If so, being controversial would not be an advantage! This means we study that which provides societal advantages, and whether something is advantage or disadvantage is decided by dominant power structures. In itself this is not necessarily a bad thing for society, but it certainly means it becomes hard to understand human behavior in its fullness since we generally make opportune selections of phenomena for study. I therefore think it to be paramount we embrace also the politically inopportune, and dare to focus on the yet little known that does not necessarily include the talents of "heroes" and "nerds", but rather seek to understand "the martyrs" to achieve a more balanced understanding of human behavior and giftedness.

My last posed question: do we actually want gifted individuals in our midst? This question is also easy to answer in a sociobiological perspective. We want $c e r$ tain kinds of gifted behaviors in our midst, namely the ones that either make us feel good in a variety of ways (entertainment) or the ones who by their skills support, maintain and develop current dominant power structures (maintenance). But as soon as a gifted individual poses a threat of some kind, an entire range of reactions is triggered in the surrounding social context. The agents of change risk becoming stigmatized. A teacher may not like to be criticized by a gifted pupil and therefore ignores him or her; a professor might not tolerate the fact that a doctoral candidate is much more bril- liant than the professor and therefore holds back on information that might benefit the student; a manager might fire someone who is better suited to be manager than he or she is; a leading politician may backstab and speak derogatory of an opponent who seems to make better sense and have better solutions to a problem; and a regime might—as history demonstrates all too clearly-eliminate dissidents with too great a potential to topple current leaders or even the entire organization or political system.

\section{Ten Hypotheses on Gifted Individuals in Different Social Contexts}

Suggesting that giftedness has societal function, as based on a sociobiological framework, makes it possible to also pose testable hypotheses regarding the fate of gifted individuals in certain contexts, for example, the following:

1. A gifted individual will be favored and promoted if their skills in some ways enhance the current power hierarchy of the group in which he or she exists.

2. The type of talent dictates social acceptance and interest or non-acceptance or negligence:

a) social maintenance functions will always be accepted and tolerated;

b) social entertainment functions will always be accepted and tolerated, unless

c) social entertainment changes function into social change and becomes a perceived threat to leaderships.

3. A gifted individual who takes on a function of societal change is accepted and promoted by a group if what they propose or do is perceived as being or generating a tangible gain and is available not too distant into the future.

4. A gifted individual who takes on a function of societal change is rarely accepted by a group if what they propose or do is perceived as a loss or gain too far away in time.

5. A gifted individual who takes on a function of societal change is never accepted by authorities (leadership/s) if what they propose or do is perceived as a threat to his/her/their position in that hierarchy. 
6. A gifted individual who takes on a function of societal change and is not accepted by authorities (leadership/s) if what they propose or do is perceived as a threat to his/her/their position in that hierarchy, will nevertheless be praised and commended by outsiders, if the gifted individual is a proponent of ideals and values adhered to by the out-group.

7. Stigmatization is a tool used to neutralize a gifted individual in a context of societal change where the gifted is seen by authorities (leadership/s) as a threat to his/her/their position in that hierarchy.

8. Marginalization is a coping strategy employed by gifted individuals in situations where they become more or less stigmatized.

\section{References}

Barnard, C. J. (2004). Animal behaviour: mechanism, development and evolution. London: Pearson/Prentice-Hall.

Baumeister, R. F. (1991). Escaping the self. Alcoholism, spirituality, masochism, and other flights from the burden of Selfhood. New York: BasicBooks.

Benhabib, S. (Ed.) (1996). Democracy and difference. Contesting the boundaries of the political. Princeton, NJ: Princeton University Press.

Cialdini, R. B., Borden, R. J., Thorne, A., Walker, M. R., Freeman, S., \& Sloan, L. R. (1976). Basking in reflected glory: Three (football) field studies. Journal of Personality and Social Psychology, 34, 366-375.

Crocker, J., \& Quinee, D. M. (2003). Social stigma and the Self: meanings, situations and Self-esteem. In F. H. Heatherton, R. E. Kleck, M. R. Hebl, \& J. G. Hull (Eds.), The social psychology of stigma (pp. 153-181). New York: The Guildford Press.

Duchaine, B., Cosmides, L., \& Tooby, J. (2001). Evolutionary psychology and the brain. Current Opinion in Neurobiology, 11(2), 225-230.

Eibl-Eibesfledt, I. (1989). Human ethology. New York: Aldine de Gruyer.

Fiedler, E. D. (1999). Gifted children: the promise of potential/the problems of potential. In V. L. Schwean, \& D. H. Saklofske (Eds.), Handbook of psychosocial characteristics of exceptional children (pp. 401-442). New York: Kluwer Academic / Plenum Publishers.

Freund, P. E. S. (1988). Bringing society into the body, 17(6), 839-864.

Gardner, H. (1988). Creative lives and creative works: a synthetic scientific approach. In R. J. Sternberg (Ed.). The nature of creativity. Contemporary psychological perspectives (pp. 298-321). Cambridge: Cambridge University Press.

Greenwald, A. G. (1980). The totalitarian ego: fabrication and revision of personal history. American Psychologist, 7, 603618.

Grossman, D. (1995). On killing. The psychological cost of learning to kill in war and society. New York: Backbay Books.
Hall J. M., Stevens, P. A., \& Meleis, A. I. (1994). Marginalization: A guiding concept for valuing diversity in nursing knowledge development. Advances in Nursing Sciences, 16(4), 23-41.

Havel, V. (1985). Power of the powerless. The citizens against the state in Central Eastern Europe. New York: M. E. Sharpe.

Hudson, R. A. (1999). Who becomes a terrorist and why? The 1999 government report on profiling terrorists. Guilford, CT: The Lyons Press.

Johnson, J. A., Germer, C. K., Efran, J. S., \& Overton, W. F. (1988). Personality as the basis for theoretical predilections. Journal of Personality and Social Psychology. 55(5), 824-835.

Kelly-Streznewski, M. (1999). Gifted grown-ups. The mixed blessings of extraordinary potential. New York: John Wiley \& Sons.

Kemper, T. D. (1990). Social Structure and Testosterone. Explorations of the Socio-bio-social Chain. London: Rutgers University Press.

Klapp, O. E. (1962). Heroes, villains and fools. Englewood Cliffs, NJ: Prentice-Hall.

Klapp, O. E. (1969). Collective search for identity. New York: Holt, Rinehart \& Winston.

Kuhn, T. (1962). The structure of scientific revolutions. Chicago, IL: The University of Chicago Press.

Landau, R. (1990). Mut zur Begabung [Courage to be gifted]. Munich, Germany: Ernst Reinhardt Verlag.

Lorenz, K. (1966). On aggression. New York: Harcourt, Brace \& World.

Machlis, J. (1979). Introduction to contemporary music (2nd ed.). London: J. M. Dent \& Sons.

Mandela, N. (1991). The struggle is my life. London: Pathfinder.

MIT Nerd Test (1998). The Official MIT Nerd Test. http://kurtz.tcimet.net/ humour/f/mit_nerd.html

Montgomery, D. (Ed.) (2000). Able underachievers. London: Whurr Publishers.

Neuberg, S. L., Smith, D. M., \& Asher, T. (2003). Why people stigmatize: toward a biocultural framework. In F. H. Heatherton, R. E. Kleck, M. R. Hebl, \& J. G. Hull (Eds.), The social psychology of stigma (pp. 31-61). New York: The Guildford Press.

Persson, R. S. (1999). High ability, society and its future: the broader curriculum. Australasian Journal of Gifted Education, 8(1), 5-14.

Persson, R. S. (2005). Voices in the wilderness: Counselling gifted students in a Swedish egalitarian setting. International Journal of Applied Counselling. 27(2), 263-276.

Russel, B. (2000). Autobiography. London: Routledge.

Russel, G. W. (1993). The social psychology of sport. New York: Springer-Verlag.

Sakharov, A. (1991). Andrei Sakharov: facets of life. New York: World Scientific Publishing.

Segerstråle, U. (2000). Defenders of the truth. The battle for science in the sociobiology debate and beyond. New York: Oxford University Press.

Shaughnessy. M. F., \& Manz, A. F. (1991). Personological research on creativity in the performing and fine arts. European Journal for High Ability, 2, 91-101.

Shekerjian, D. (1990). Uncommon genius, How great ideas are born. New York: Viking.

Simonton, D. K. (1988). Creativity, leadership, and chance. In R. J. Sternberg (Ed.). The nature of creativity. Contemporary 
psychological perspectives (pp. 386-428). Cambridge: Cambridge University Press.

Sternberg, R. J., \& Lubart, R. L. (1995).Defying the crowd. Cultivating creativity in a culture of conformity. New York: The Free Press

Storr, A. (1972). The dynamics of creation. London: Penguin Books.

Suyono, H. (1996). The gifted children: human resources development to meet the Twenty-First Century. In U. Munandar, \& C. Semiawan (Eds.). Optimizing excellence in human resource development (Proceedings of the Fourth Asia-Pacific Conference on Giftedness, Jakarta, 4-8 August) (pp. 71-77). Jakarta, Indonesia: University of Indonesia Press.

Tee Tao, C., \& Ling Quah, M. (1999). The Knowledge, Volition, and Action Programme in Singapore: the effects of an experimental intervention programme on high ability achievement. High Ability Studies, 10(1), 23-36.

Valladares, A. (2001). Against all hope. A memoire of life in Castro's Gulag. New York: Encounter Books.

Vorbeck, M. (1992). Competence and responsibility: education for a united Europe. In E. A. Hany, \& K. A. Heller (eds.).
Competence and responsibility. The Third European Conference of the European Council for High Ability. Volume 1: Abstracts (pp. 185-189). Göttingen, Germany: Hogrefe \& Huber Publishers.

Wallace, B., \& Adams, H. B. (Eds.) (1993). Worldwide perspective on the gifted disadvantaged. Bicester, UK: A B Academic Publishers.

Walsh, A. (2003). Introduction to the biosocial perspective. In A. Walsh, \& L. Ellis (Eds.),Biosocial criminology: challenging environmentalism's supremacy (pp. 3-12). New York: Nova Science Publishers.

Wilms, D. (1986). Patron's opening address. In A. J. Cropley, K. K. Urban, H. Wagner, \& W. Wieczerkowski (Eds.). Giftedness: a continuing worldwide challenge (pp. 16-20). New York: Trillium Press.

Wilson, E. O. (2000). Sociobiology. The new synthesis. Cambridge, MA: Harvard University Press.

Wilson, E. O. (2004). On human nature. Cambridge, MA: Harvard University Press.

Wu, H., \& Vecsey, G. (1996).Troublemaker: one man's crusade against China's cruelty. New York: Crown Publishers. 